CORPORATION TAX 


\title{
CORPORATION TAX
}

\author{
Third edition
}

H. C. D. RANKIN and D. M. CATTERALL

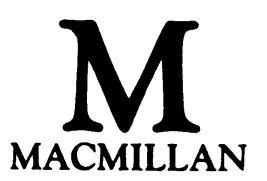

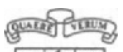

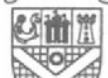


(C) H. C. D. Rankin 1977

C) H. C. D. Rankin and D. M. Catterall 1985, 1989

All rights reserved. No reproduction, copy or transmission of this publication may be made without written permission.

No paragraph of this publication may be reproduced. copied or transmitted save with written permission or in accordance with the provisions of the Copyright Act 1956 (as amended), or under the terms of any licence permitting limited copying issued by the Copyright Licensing Agency, 33-4 Alfred Place, London WC1E 7DP.

Any person who does any unauthorised act in relation to this publication may be liable to criminal prosecution and civil claims for damages.

First edition 1977 (published by Gee \& Co. Ltd)

Second edition 1985 (published by Van Nostrand Reinhold (UK) Co. Ltd)

Third edition 1989 (published by Macmillan Education Ltd)

Published by

MACMILLAN EDUCATION LTD

Houndmills, Basingstoke, Hampshire RG21 2XS

and London

Companies and representatives

throughout the world

Published in association with the

Institute of Chartered Accountants of Scotland

Typesetting by Footnote Graphics, Warminster, Wilts

British Library Cataloguing in Publication Data

Rankin, H.C.D. (H. Cunnie D.)

Corporation tax for students.-3rd ed./H.C.D. Rankin and D.M.

Catterall

1. Great Britain. Corporation tax

I. Title II. Catterall, D.M. (Denise M.) $336.24^{\prime} 3^{\prime} 0941$

ISBN 978-0-333-48809-6

ISBN 978-1-349-19835-1 (eBook)

DOI 10.1007/978-1-349-19835-1

The law is the state-of-the-art as at 13 September 1988. 


\section{CONTENTS}

Preface

Abbreviations

xi

xiii

1 The Computation of Profit

1.1 Introduction

1.2 The charge to corporation tax 3

1.3 Accounting periods 3

1.4 Financial years 5

1.5 Computation of profits: application of income tax principles

1.5.1 Schedule D Case I 7

1.5.2 Schedule D Case III 8

1.5.3 Income from which income tax has been deducted 9

$\begin{array}{ll}\text { 1.5.4 Building society interest } & 12\end{array}$

1.5.5 Distributions received 12

1.6 Computation of profits: application of capital gains tax principles $\quad 12$

$\begin{array}{lll}1.7 & \text { Charges on income } & 14\end{array}$

1.7.1 Excess charges 15

1.7.2 Deduction of income tax from charges paid 18

1.8 Accounting for income tax 19

1.9 Rates of corporation tax 21

1.9.1 Small company rate 22

1.9.2 Marginal small companies relief 23

1.10 Date for payment of corporation tax 26

1.11 General administrative provisions 27

1.12 Interest on overdue corporation tax 27

1.13 Repayment supplements 30

1.14 Pay and file 31

Question 1 31 
2 Capital Allowances 33

2.1 Principles of capital allowances 33

2.2 Industrial buildings allowances 34

2.3 Industrial buildings or structures 34

2.3.1 Initial allowances 37

2.3.2 Writing down allowances 38

2.3.3 Balancing adjustments 40

2.3.4 Special case of balancing adjustment $\quad 42$

2.3.5 Residue of expenditure 43

2.3.6 Purchaser of second-hand used

2.4 Qualifying hotels 46

2.4.1 Writing down allowances 48

2.4.2 Balancing adjustments 48

2.5 Small and very small workshops 48

2.6 Enterprise zones 49

2.7 Plant and machinery $\quad 50$

2.7.1 First year allowances $\quad 51$

2.7.2 Writing down allowances 52

2.7.3 Disposal value and balancing charge 55

2.7.4 Balancing allowances and permanent

2.7.5 Motor cars $\quad 56$

2.7.6 Short life assets $\quad 59$

2.7.7 Hire purchase $\quad 60$

2.7.8 Building alterations and machinery

2.7.9 Subsidies and investment grants 62

2.7.10 Lessors of plant and machinery 62

2.8 Other reliefs for capital expenditure 63

2.9 Agricultural land and buildings 64

2.9.1 Balancing events 64

2.9.2 Allowances available to new owner 65

2.9.3 Division of allowances where no

2.10 Scientific research $\quad 67$

2.11 Know-how $\quad 69$

2.12 Patent rights $\quad 70$

Question 2 70 
3 The Imputation System 72

3.1 The principles of the imputation system 72

3.2 The nature of distributions $\quad 75$

3.2.1 Distribution of cash or other assets $\quad 76$

3.2.2 Bonus issues coupled with repayment of capital and bonus issues of redeemable capital

3.2.3 Interest payments in certain circumstances $\quad 79$

3.2.4 Purchase by a company of its own shares $\quad 80$

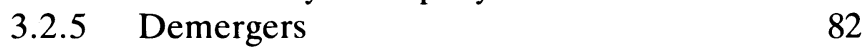

3.3 Qualifying and non-qualifying distributions 83

3.4 Franked investment income $\quad 84$

3.5 Franked payments $\quad 84$

3.6 Set-off advance corporation tax $\quad 86$

3.6.1 Set-off of advance corporation tax against corporation tax on profits $\quad 87$

3.6.2 Restriction of advance corporation tax set-off 87

3.6.3 Advance corporation tax rate change during accounting period $\quad 89$

$\begin{array}{lll}3.7 & \text { Surplus advance corporation tax } & 90\end{array}$

3.7.1 Carry back of surplus advance corporation tax

3.7.2 Carry forward of surplus advance corporation tax

3.8 Uses of surplus advance corporation tax: antiavoidance

3.9 Accounting for advance corporation tax 96

3.10 Surplus franked investment income 98

3.11 Change in rate of advance corporation tax: general points

Question 3

4 The Computation and Use of Losses 103

4.1 Introduction 103

4.2 Carry forward of trading losses 103

4.3 Loss set-off against other profits of same accounting period 
4.4 Loss set-off against profits of previous accounting periods

4.4.1 Loss arising in accounting period of less than 12 months

4.4.2 Interaction between loss reliefs and charges

4.5 Terminal loss relief

4.6 Set-off of trading losses and other items against surplus franked investment income

4.7 Effect of S.242 claim in subsequent years 124

4.8 Other losses and deficits

4.9 Consequences of loss claims

Question 4

5 Groups of Companies

5.1 The nature of a group of companies 130

5.2 Group relief

5.2.1 Group relief for trading losses 133

5.2.2 Group relief for excess charges

5.2.3 Corresponding accounting periods

5.2.4 Companies joining or leaving group

5.2.5 Relation of group relief to other relief: the claimant company

5.2.6 Payment for group relief

5.3 Group income and interest

5.4 Surrender of ACT

5.5 Transfer of chargeable assets within groups 151

5.6 Consortia

5.6.1 Surrender of trading losses

5.6.2 Payment of dividends and charges under S.246 election

Question 5

6 Close Companies

6.1 The nature of close companies 158

6.1.1 Close company: definition 159

6.1.2 Participator

6.1.3 Control 160

6.1.4 Associate 161

6.1.5 Companies with a public interest 164 
6.2 The extended meaning of distributions 167

$\begin{array}{lll}6.3 & \text { Loans to participators } & 168\end{array}$

$\begin{array}{lll}6.4 & \text { Relevant income } & 170\end{array}$

6.4.1 Distributable income 171

6.4.2 Business requirements 172

6.5 Excess of relevant income over distributions 173

6.6 Maximum relevant income 174

6.6.1 Cessations and liquidations 179

6.6.2 Inspector's clearance 179

6.7 Apportionment of excess 179

6.7.1 Excess of $£ 1,000$ or less 181

6.7.2 Apportionment of interest 181

6.7.3 Dividend restriction 181

6.8 Another definition of close company 181

Question 6 182

7 Foreign Element 183

$\begin{array}{lll}7.1 & \text { Introduction } & 183\end{array}$

$\begin{array}{lll}7.2 & \text { Residence } & 184\end{array}$

7.2.1 Position before 15 March $1988 \quad 184$

7.2.2 Position from 15 March $1988 \quad 185$

$\begin{array}{lll}7.3 & \text { Exit charge } & 186\end{array}$

$\begin{array}{lll}7.4 & \text { Payment of tax } & 187\end{array}$

7.5 Migration and Treasury consents 187

$\begin{array}{lll}7.6 & \text { Inward investment } & 189\end{array}$

7.7 Outward investment 193

7.8 Double tax relief 194

7.9 Controlled foreign companies 197

Question 7 199

Appendix 1 Corporation tax work form 201

Appendix 2 Rates of IBA 203

Appendix 3 Examination questions 8-13 204

Appendix 4 Solutions to questions 1-13 214

Appendix 5 Table of statutes 242

Index 246 


\section{PREFACE}

This is the third edition of Corporation Tax, which was first published over a decade ago. Since that time the book has established itself as a favourite text of students studying for the examinations of accountancy and other professional bodies and those of universities and colleges.

The text of this third edition has been completely revised and updated, much new material being included in the chapters on Capital Allowances (Chapter 2) and the Foreign Element (Chapter 7). As well as a full treatment of the Computation of Profit in Chapter 1 and the Computation and Use of Losses in Chapter 4, Close Companies continue to be fully considered in Chapter 6 . Questions of final examination standard are placed at the end of each chapter, and in addition a selection of examination questions (with worked solutions by the authors) from the final examinations of the Institute of Chartered Accountants of Scotland, the Institute of Chartered Accountants in England and Wales, the Institute of Chartered Secretaries and Administrators and the Chartered Association of Certified Accountants are included (Appendixes 3 and 4). We are grateful to these bodies for their permission to use examination questions and other materials published by them.

Members of the accountancy and other professions who are looking for an overview of the principles of corporation tax, written in a clear descriptive style, will find it in this volume.

Many people assisted in the preparation of this edition. Penny Tuck BSc., ACA ATII and Iain Robertson MA, both with Deloitte Haskins \& Sells, Cambridge, updated much of the text and statutory references; Janet Rankin MA CA with Price Waterhouse, London, revised chapter and examination questions; Mary Woodley with Rankin \& Co., Edinburgh, processed the new texts and material with unfailing good humour and intelligence. These and the many other persons who assisted in various ways have our sincere thanks. 
xii Preface

The authors hope that many new readers of Corporation Tax will find understanding and examination success by studying this new edition.

H. C. D. Rankin

D. M. Catterall 


\section{ABBREVIATIONS}

$\begin{array}{ll}\text { ABA } & \text { Agricultural buildings allowance } \\ \text { ACT } & \text { Advance corporation tax } \\ \text { AP } & \text { Accounting period } \\ \text { BA } & \text { Balancing allowance } \\ \text { CA 1985 } & \text { Companies Act 1985 } \\ \text { CAA 1968 } & \text { Capital Allowances Act 1968 } \\ \text { CFC } & \text { Controlled foreign company } \\ \text { CGTA 1979 } & \text { Capital Gains Taxes Act 1979 } \\ \text { FA } & \text { Finance Act (e.g., Finance Act 1978) } \\ \text { F(2)A 1987 } & \text { Finance (No.2) Act 1987 } \\ \text { FII } & \text { Franked investment income } \\ \text { FY } & \text { Financial year } \\ \text { FYA } & \text { First year allowance } \\ \text { IA } & \text { Initial allowance } \\ \text { IBA } & \text { Industrial buildings allowance } \\ \text { IDA 1982 } & \text { Industrial Development Act 1982 } \\ \text { OECD } & \text { Organisation for Economic Co-operation and } \\ \text { Para. } & \text { Development } \\ \text { PAYE } & \text { Paragraph (of an Act schedule or an Act section or } \\ \text { S. and Ss. } & \text { subsection) } \\ \text { Sched. } & \text { Section and sections (of an Act) } \\ \text { SLA } & \text { Schedule (of an Act) } \\ \text { TA 1970 } & \text { Income and Corporation Taxes Act 1970 } \\ \text { TA 1988 } & \text { Income and Corporation Taxes Act 1988 } \\ \text { TMA 1970 } & \text { Taxes Management Act 1970 } \\ \text { UFII } & \text { Unfranked investment income } \\ \text { WDA } & \text { Writing down allowance } \\ \text { WDV } & \text { Written down value } \\ & \end{array}$

